на создание статусного контраста. Такими средствами выступают антонимические пары полнозначных слов и специальных тематических групп, имена и фамилии персонажей, этикетные клише (в том числе специальные), бытовые детали, основанные на особенностях функционирования грамматических категорий, формул социально окрашенной речи. Выявлены два приёма, способствующие реалистическому отображению социального статуса персонажей: приём взаимного снижения статуса социально контрастных персонажей и приём сочетания невербальных и вербальных средств выражения социального статуса.

Ключевые слова: социальный статус, языковые средства, языковая картина мира, социальная оценка персонажа, идиостиль.

Svitlana Ie. STEPANOVA,

graduate student of the Russian Language Department, Odessa I. I. Mechnikov National University,

24/26 Frantsuzkyi blvd., Odessa, 65058, Ukraine; tel.: +38 098 2063230; e-mail: fudimkaa@mail.ru;

ORCID ID: 0000-0002-2855-3657

\title{
STATUS SPEECH CHARACTERISTICS OF ART CHARACTERS IN RUSSIAN LITERATURE OF THE BEGINNING OF 20 ${ }^{\mathrm{TH}}$ CENTURY
}

Summary. The article describes a study on the issue of the dependence of human speech on various aspects of speaker's social status. Material of research: texts of A. P. Chekhov's stories "Thick and thin», M. A. Bulgakov "Towel with a rooster", V. M. Inber "Solovey \& Roza / Nightingale and Rose». The purpose of the work is to determine the role of language means expressing the estate, career, property, professional, cultural status of characters in the fiction. The object of study is various language means that are able to reflect the social status of a character in his communicative behavior. The subject of the research is the status meaning assigned to these language means. In the process of carrying out the research, various procedures of the sociolinguistic analysis method are combined with methods of semantic, grammatical, phonetic, semiotic and multivariate analysis, methods of analysis of non-verbal communicative means and probabilistic forecasting, as well as descriptive and historical-descriptive methods. As a result of the study, the language means of expression of the class, career, property, professional, cultural status of the characters were identified and analyzed. Conclusions are drawn. The language tools used to express the character's social status are mainly aimed at creating a status contrast. Anthonymic pairs of full-valued words and special thematic groups, names and surnames of characters, etiquette clichés (including special ones), household details based on the functioning of grammatical categories, and socially colored speech formulas are such means. Two techniques have been identified that contribute to the realistic display of the social status of characters: the technique of mutually lowering the status of socially contrasting characters and the technique of combining non-verbal and verbal means of expressing social status.

Key words: social status, language means, language picture of the world, social assessment of a character, idiostyle.

Статтю отримано 22.10.2019 p.

http://dx.doi.org/10.18524/2307-4558.2019.32.187791

УДК 811.161.2’276.3

\section{УЛЬЯНОВА Вікторія Олегівна,}

викладач кафедри іноземних мов природничих факультетів Одеського національного університету імені

I. I. Мечникова; Французький бульвар, 24/26, м. Одеса, 65058, Україна; тел.: +38 0975276506 ;

e-mail: vikaromanenko17@gmail.com; ORCID ID: 0000-0002-2821-1833

\section{МОВНА ОСОБИСТІСТЬ УКРАЇНСЬКОЇ ДІЛОВОЇ ЖІНКИ НА СТОРІНКАХ ЖУРНАЛУ "ЖIHKA»}

Анотація. У представленій статті проаналізовано особливості вербалізації образу ділової жінки на сторінках журнального періодичного видання (Жіінка». Мета дослідження - систематизувати особливості вербальних засобів репрезентації ідентичності ділової жінки в текстах періодичного видання; описати формування мовними засобами стереотипів фемінності у пострадянський період історії України; за даними публіцистичних текстів проаналізувати трансформації традиційних ґендерних стереотипів. Предметом вивчення є особливості комунікативної особистості української ділової жінки у добу незалежності держави. Результати аналізу особливостей мовленнєвої поведінки ділової жінки уможливлюють зробити наступні висновки: у текстах статей наявні англіцизми, запозичені терміни на позначення нових стосунків в економіці; частотними є професіоналізми та шаблонні конструкції без емоційного забарвлення. Мовлення жінок увиразнюється вставними словами, які не стають джерелом зайвої інформації; їх уживання допомагає мовцеві зорієнтуватися, зосередитися, а також робить висловлення більш організованим і чітким. Тексти сучасного періодичного жіночого видання характеризуються активізацією різноманітних словотворчих компонентів, наприклад, на позначення найвищої оцінки: супервулен, суперзірка, супербінал, мегашоу та ін.; у мовленні сучасної ділової жінки на сторінках журналу багато іншомовних слів, особливо це помітно у процесі описання досвіду роботи українських жінок на світовому ринку. 
Вищезазначене пояснюється зміною ціннісних орієнтирів особистості, відкритістю українського пострадянського суспільства та проникненням у різні сфери життя суспільства нових понять і явищ.

Ключові слова: мовна особистість, соціолінгвістика, ділова жінка, журнальне періодичне видання “Жінка», ґендерний стереотип, гендерна ідентичність, фемінність.

Постановка проблеми. У час домінування в лінгвістичних розвідках антропоцентричного підходу та дослідження мови в соціокультурному аспекті особливо актуальною постає проблема репрезентації людини в мові. Суспільні й мовні зміни тісно пов'язані між собою, отже, мова фіксує відбитки потужних трансформацій, суттєвих перетворень, значних подій, що відбуваються в соціумі. Актуальним у сучасній лінгвістиці є поняття мовноӥ особистості, яке по-різному тлумачать науковці. Утім, вони збігаються в загальному розумінні того, що мовна особистість репрезентує в мовленнєвій діяльності найхарактерніші особливості певної історичної доби.

Попередні дослідження проблеми. Феномен мовної особистості представляє неабиякий інтерес для науковців, які працюють у різних галузях гуманітарного знання: психологів, філософфів, соціологів, етнокультурологів та ін. Лінгвістичну концепцію мовної особистості започаткували у вітчизняному мовознавстві І. Голубовська, С. Заостровська, О. Заостровський, С. Єрьоменко, М. Іваницька, А. Романченко, в зарубіжному - С. Воркачов, В. Карасик, Ю. Караулов, В. Нерознак та ін. Дослідження мовної особистості стали актуальною і перспективною проблемою сучасної лінгвістичної парадигми. Науковці активно долучаються до вирішення нагальних питань і лінгвістичної персонології (Ф. Бацевич, А. Загнітко, Т. Космеда та ін.).

Формулювання завдань дослідження. Метою нашої роботи є систематизація особливостей вербальних засобів репрезентації ідентичності ділової жінки в текстах періодичного видання. У статті зроблено спробу описати формування мовними засобами стереотипів фемінності в пострадянський період історії України, а також проаналізувати на матеріалі публіцистичних текстів трансформації традиційних ґендерних стереотипів. Предметом розгляду визначено особливості комунікативної особистості ділової жінки незалежної України.

Виклад основного матеріалу. Мовну особистість характеризує багаторівневість у межах когнітивної, вербально-семантичної, комунікативної та емотивної сфер, які зазнають певного впливу пануючих у суспільстві гендерних стереотипів.

Центром сучасних наукових інтересів лінгвістів є тексти, які репрезентують різні соціокультурні сфери життя людей. Особливим попитом завжди користувалися журнали для жінок [1]. Наприкінці XX століття формується поняття (глянцевий журнал), або "глянець), змінюється змістове наповнення, яке відповідає часу та потребам читачок. Н. Клименко зазначає, що “у жіночих глянцевих видань є своя характерна стилістика, не тільки словесна, а й структурна, така, що стосується також і оформлення. У числі перших ці видання відмовилися від чіткого розміщення матеріалів за змістом...) [2]. У глянцевих журналах наочність є головною рисою, бо ця друкована продукція призначена для відпочинку. Такі журнали практично не розраховані на читання, вони захоплюють людину не своєю інформативною змістовністю, а яскравим образом, що символізує успіх, щастя, багатство [2].

Українськомовний журнал (ЖЖінка) (до 1991 року виходив під назвою "Радянська жінка») також змінюється та набуває деяких ознак глянцю: спостерігається більше наочності, реклами, полегшення змісту статей. Сама рубрикація теж відчула змін. Це пов'язано з переосмисленням ціннісного наповнення. На сторінках періодичного видання активізується імідж ділової жінки. Сучасні українки прагнуть реалізувати себе в суспільстві, але на тлі традиційних стереотипів діловій жінці належить навчитися поєднувати дві протилежні ролі: сімейну і професійну. Портрет жінки, затребуваної часом, - це портрет упевненої, незалежної, розумної людини, яка добре володіє собою, вміє досягати поставлених цілей і справлятися зі складною ситуацією.

В умовах нестабільної політичної та економічної ситуації незалежної України ринок праці переживає важкі часи. У статті “Переворот? У малому бізнесі...”. (рубрика "Жкінка і ринок") наголошується на тому, що «вистачить пальиів на руках, щоб перелічити жінок-підприємнищь», а також, констатує автор, стали звичними фрази “фемінізація бідності” та “у безробіття жіноче обличчя" [6, с. 11]. У тексті статті використано лексеми та словосполучення на позначення нових економічних реалій: тендер, податкові канікули, консалтингові послуги, кредитна система, бізнес-план, бізнес-інкубатор.

Мовлення героїні вирізняє вживання шаблонних словосполучень: брати кредити; nid n'ятнадиять річних, - а також фразеологізмів: заганяти у глухий кут; звести на слизьке тощо. Наприклад: Підприємства змушені брати кредити під карколомні відсотки..., під п'ятнадиять прочентів річних..., не заганяти краӥну у глухий кут... [6, с. 11]. У наведеному прикладі паралельно вжито лексеми прочент і відсоток, але частіше - слово проуент, як і в інших текстах статей. Цікаво, що за радянських часів відсоток вважали мало не націоналістичним словом. Тільки у найсучасніших випусках спостерігаємо перевагу на користь другої лексеми, що пояснюється загальною тенденцією до вживання українських термінів.

У 1980-ті рр. з'являються статті з критикою використання терміну відсоток. Слово вважалося штучним і застарілим, а також називалося (архаїзмом» і “діалектизмом». Пропонували використо- 
вувати замінник процент з обгрунтуванням пріоритетного вживання інтернаціональних термінів. У вищезазначеному прикладі паралельно вжито процент і відсоток, але ми помітили частіше використання у статтях лексеми прочент [3].

У вищезгаданій статті ми звернули увагу на лексему партократи: До того ж постійні волання, шзо партократи - злочиниі... [6, с. 11]. Термін походить від поняття партократія, який тлумачать як панування у політичній системі суспільства однієї чи групи споріднених партій, що зосереджують у своїх руках управління всіма сферами суспільного життя.

Жінка-підприємець у своєму мовленні постійно вживає вставні слова, які активізують увагу співрозмовника, а також вказують на порядок думок, зв'язок між ними: зрозуміло, пригадайте, шоправда, приміром, повірте, скажіть, правда, на жаль, зрештою, безперечно, можливо, соромно казати [6, с. 11].

Показовим на вербально-семантичному рівні головної героїні публіцистичного тексту є використання дієслів: вибороти, здобути, виборювати, відстоювати, які характеризують жінку як наполегливу особистість: А от посаду керівника Агентства довелося виборювати, відстоювати... То довга історія, як я виборола посаду директора. Саме виборола, вдобула [6, с. 11].

У статті під назвою “Усього можна навчитися) (рубрика (Жһiнка і ринок)) розповідачка ділиться спільним досвідом з чоловіком про відкриття (швейного салону»: Кожтів на ремонт бракувало - банк кредиту не давав. Робили все салотужки. Автор статті наводить аргументи героїні, чому салон назвали ім'ям чоловіка, а не її власним іменем: Салон назвали іменем Сергія, бо хоч ие їхня давня спільна мрія - створювати гарні моделі, та Віта йшла до неї без перешкод, Сергієві їх довелося долати з дитинства. Ще хлоп'ял він грався маминими брошками. На уроках малював однокласничям моделі модного одягу. Це дивувало й дратувало батька: якісь жіночі вподобання у сина... [11, с. 6$]$.

Цікавим для аналізу вважаємо мовний портрет незалежної жінки зі статті „Тільки б не вапізно...” (рубрика “Сповідь)). Ось як вона описує саму себе: Самостійна, впевнена у собі, приваблива жінка, шо володіє секретами боді-й фреисбілдингу, вміло керує, принаймні на людях, власною психікою. Хазяйновита. ... Одне слово, на людях я видаюсъ мало не «бетеером», щоправда, з формами, які ще здатні схвилювати чоловічу увагу [10, с. 8]. Наведений фрагмент свідчить про руйнацію традиційного стереотипу фемінності, який передбачав скромність у всьому в процесі презентації самої себе. Успішна жінка-керівник у 1990-х рр. володіє не тільки новітніми технологіями лідерства, що були розроблені на Заході, а й технологіями self-made man (людини, яка зробила себе сама). Маскулінітив self-made man є більш частотним, на відміну від self-made woman, що має вужче значення. Мовлення такої жінки свідчить про ймовірне знання англійської: вона вставляє англіцизми в канву розповіді про себе: бодібілдинг, файсбілдинг. Вона використовує прикметники з позитивною конотацією: впевнена, приваблива, з формами, які хвилюють чоловіків. Одним словом - супервумен! У цьому контексті спостерігаємо активізацію словотворчих елементів, що виражають найвищий рівень оцінки, характерний для жіночого мовлення: супервулен, суперзірка та ін.

Героїня використовує просторічну метафоро, провівши паралель між собою та “бетеером». Така самооцінка свідчить про її зухвалість і про те, що вона може бути дуже різною - це часова ознака мовної особистості сучасних жінок-керівниць. Щирість і відвертість прямої мови свідчить про самоаналіз і впевненість у собі: "Співробітничі заздрять мені, моїй свободі від повсякденних домашніх турбот, зайвих переживань. Але, знаю, часто жаліють через мою салотність. Навіть невдаха Люсъка співиуває і кілька разів намагалася нав'язати мені зустрічі з якимись знайомими чоловіками) [10, с. 2]. Нелітературні форми в характеристиці співробітниці (невдаха, Люсъка, бездарна жінка тощо) дають можливість визначити соціальний статус керівника в минулому - вона пройшла шлях від простої робітниці до керівника найвищого рангу, саме тому виділяємо два типи мовленнєвої культури лідера: літературно-розмовний і фамільярно-розмовний.

Досвід роботи жінок на взуттєвому підприємстві висвітлено у статті “Крок ва кроком» (рубрика (Жкіна і ринок)): ...cеред пращюючих, у тому иислі й серед керівників різних підрозділів, понад вісімдесят відсотків - жінки [5, с. 2]. В одному з номерів журналу "Радянська жінка» виробництво взуття називають традиційно жіночою галуззю народного господарства [5, с. 7]. Отже, за даними статті, робимо висновок про те, що протягом десяти років у легкій промисловості залишилися старі стереотипи, та й у нашій країні в цілому нічого не змінилося.

У цій же рубриці “Жінка і ринок» стаття під назвою “Зі сприятливою аурою» розповідає про непростий досвід директора ринку Тамару Оніщенко: Здавалось, щуо на иій посадi не втримаюсь й тижня. Сказати, що було важко - нічого не сказати... Перший рік ніби по льоду ходила... [5, с. 4-5]. Образні й емоційні висловлення героїні характеризують її мовлення як типово жіноче мовлення міського жителя; порівняння ходити ніби по льоду дає підстави вважати домінуючим типом її мовленнєвої культури - літературно-розмовний.

Мовний портрет успішної жінки розкривається у статті «Професіонали вавжди на часі) (рубрика “Гість номера»): За своєю зовнішністю Валентина Василівна типова українка: нижче середнього зросту, з красивим обличчям $і$ стрункою статурою, завжди елегантно $i$ зі смаком одягнена. Мудрість жінки-керівника порівнюють з мудрістю княгині Ольги чи Роксолани: Привер- 
тають увагу чарівність, иляхетність у руках $i$ мудрість у поведіниі иієї неординарної жінки [8, с. 8-9]. Очевидно, що в тексті акцент зроблено на національно-культурну ознаку героїні, що було актуально на початку XXI ст.

У статті “Формула успіху» розповідається про Жіночу селянську лігу “Оріана» і про те, що члени ліги роблять для того, щоб навчити жінок встояти у складних економічних обставинах. Одним із виходів зі скрутного ставища може бути власна справа. Ключовими словами статті є наступні: бізнес та бізнесовий (використовується десять разів), підприємець / підприємниця (шість разів), власна справа (чотири випадки використання), напр.: Основна мета иленів «Оріани» - навиитися самим й інших навиити грамотно й фахово започаткувати власну справу. Допомогти ж у розвитку та становленні власного бізнесу підприємниць покликаний бізнес-центр, робота над створенням якого вже розпочалася... [12, с. 2].

Часовою ознакою мовної особистості жінки, за даними публіцистичних текстів, є вживання запозичених іншомовних слів при вербалізації ринкового досвіду українських підприємниць: бізнес-леді ("Бізнес-леді та й просто ледi») [4, с. 22]; супервумен ("Тількі б не запізно») [10, с. 2]; тренінг (“Форлула успіху») [12, с. 2,]; selfmade woman ("Проекm selfmade woman») [7, c. 6]; startup, aбo стартап ("Startup: бізнес на ідеї») [14, с. 8] тощо.

Це пояснюється, з одного боку, тим, що пострадянське українське суспільство зорієнтовано на західний спосіб життя, а з іншого - активний процес запозичення іншомовних лексичних одиниць пов'язаний із відкритістю нашого суспільства, культурними й ціннісними орієнтирами особистості та проникненням у різні сффери життя нових понять і явищ.

За даними психологів, і чоловіки-, і жінки-керівники, як правило, працюють без вихідних і демонструють постійну готовність говорити про свою справу. Негативні наслідки такого ставлення до роботи є очевидними. Ділові жінки мають навчитися правильно відпочивати, адже ие найактуальніший тренд съогодення: ...вигорати на роботі вже не круто, не вигорати - реально (стаття “Це не горить» у рубриці “Психологія») [13, с. 36]. У статті говориться про професійне вигорання, яке дешоо перегукується зі словниковим значенням: перем. Бурхливо виявивиись, зникати, проходи$m u[9$, т. 6, с. 155]. У психології таке значення набуло негативного відтінку, зокрема, відсутність зацікавленості і мотивації в роботі: як горіти своєю справою, а не згасати. У цитаті наявна інтертекстуальність, яка формує певний підтекст. Фраза вигорати на роботі вже не круто, по-перше, 6 проявом просторічного типу мовленнєвої культури, по-друге - прикладом алюзії, що явно натякає на ставлення до роботи в радянські часи, отже, має негативну оцінку.

Висновки. Таким чином, аналіз характерних ознак мовної особистості української ділової жінки на сторінках періодичного видання (Жінка), дає підстави стверджувати наступне. По-перше, в текстах статей частотними є англіцизми, запозичені терміни для позначення нових реалій в економіці (тендер, кредитна система, бізнес-план). По-друге, у мовленні сучасної жінки-лідера мінімум слів у переносному значенні, проте домінують професіоналізми та шаблонні конструкцій без емоційного забарвлення (брати кредити; під n'ятнадиять річних), що є ознакою маскулінного офбіційно-ділового мовлення. По-третє, використання жінками вставних слів допомагає мовцеві зорієнтуватися, зосередитися, робить висловлення структурованим і чітким. Тексти сучасного періодичного жіночого видання характеризуються активізацією різноманітних словотворчих компонентів, наприклад, супервумен, суперзірка та ін.

Мовлення сучасної ділової жінки увиразнюється великою кількістю іншомовних слів. Це пояснюється зміною ціннісних орієнтирів особистості, відкритістю українського суспільства та проникненням у різні сфери життя нових понять і явищ.

\section{Лime ра тура}

1. Здоровега В. Й. Теорія і практика радянської журналістики : основи майстерності, проблеми жанрів. Львів : ПАIC, 2004. 268 c.

2. Клименко Н. О. Специфіка рубрикації та своєрідність подання матеріалу в жіночих глянцевих журналах. Держава та регіони. Сер. : Сочіальні комунікачї̈. Запоріжжя, 2012. № 1. С. 65-72.

3. Панько Т. I., Кочан I М., Мацюк Г. П. Українське термінознавство : підручник. Львів : Світ, 1994. 214 с.

4. Бізнес-леді та й просто леді. Жтінка. 2004. № 1. С. 22.

5. Крок за кроком. Ӟіннка. 1999. № 8. С. 2.

6. Переворот? У малому бізнесі... ЖЖінка. 1994. № 6. С. 11.

7. Проект selfmade woman. Ж⿱㇒ннка. 2017. № 1. С. 6.

8. Професіонали завжди на часі. ЖЖінка. 2004. № 1. С. 8-9.

9. Словник української мови : в 11 т. / АН УРСР. Інститут мовознавства; за ред. І. К. Білодіда. Київ : Наук. думка, 1970-1980.

10. Тільки б не запізно... Жінка. 1994. № 7. С. 8.

11. Усього можна навчитися. Жіінка. 1994. № 5. С. 6.

12. Формула успіху. Жінка. 2000. № 7. С. 2.

13. Це не горить. ЖЖінка. 2019. № 6. С. 36.

14. Startup : бізнес на ідеї. жЖінка. 2017. № 1. С. 8. 
1. Zdoroveha, V. I. (2004), The theory and practice of Soviet journalism : basics of skill, problems of genres [Teoriya $i$ praktyka radyans'koyi zhurnalistyky : osnovy maysternosti, problemy zhanriv], PAIS, Lviv, 268 p.

2. Klymenko, N. O. (2012), Specificity of rubrication and originality of presentation of material in women's glossy magazines, State and regions, Series : Social Communications [Spetsyfika rubrykatsiyi ta svoyeridnist' podannya materialu v zhinochykh hlyantsevykh zhurnalakh, Derzhava ta rehiony, Ser. : Sotsial'ni komunikatsiyi], Zaporizhzhia, No. 1, pp. $65-72$.

3. Pan'ko, T. I., Kochan, I M., Matsyuk, H. P. (1994), Ukrainian terminology [Ukrayins'ke terminoznavstvo : pidruchnyk], Svit, L'viv, 214 p.

4. Business women and just women (2004), Woman [Biznes-ledi ta y prosto ledi, Zhinka], Kyiv, No. 1, p. 22.

5. Step by step (1999), Woman [Krok za krokom, Zhinka], Kyiv, No. 8, p. 2.

6. Revolution? In small business... (1994), Woman [Perevorot? U malomu biznesi..., Zhinka], Kyiv, No. 6, p. 11.

7. Selfmade woman project (2017), Woman [Proekt selfmade woman, Zhinka], Kyiv, No. 1, p. 6.

8. Professionals are always on time (2004), Woman [Profesionaly zavzhdy na chasi, Zhinka], Kyiv, No. 1, p. 8-9.

9. Bilodid, I. K. (ed.) (1970-1980), Dictionary of the Ukrainian language : in 11 vols. [Slovnyk ukrayins'koyi movy : $v 11$ t., red. I. K. Bilodid], AS of Ukraine SSR, Inst. of linguistics, Naukova dumka Publishing house, Kyiv.

10. It would be too late... (1994), Woman [Til'ky b ne zapizno..., Zhinka], Kyiv, No. 7, p. 8.

11. You can learn everything (1994), Woman [Us'ogo mozhna navchytysya, Zhinka], Kyiv, No. 5, p. 6.

12. The formula of success (2000), Woman [Formula uspikhu, Zhinka], Kyiv, No. 7, p. 2.

13. It's not burning (2019), Woman [Tse ne horyt', Zhinka], Kyiv, No. 6, p. 36.

14. Startup : Business on Ideas (2017), Woman [Startup : biznes na ideyi, Zhinka], Kyiv, No. 1, p. 8.

\section{УЛЬЯНоВА Виктория Олеговна,}

преподаватель кафедры иностранных языков естественных факультетов Одесского национального университета имени И. И. Мечникова; Французский бульвар 24/26, г. Одесса, Украина; тел.: +38 0975276506 ; e-mail: vikaromanenko17@gmail.com; ORCID ID: 0000-0002-2821-1833

\section{ЯЗЫКОВАЯ ЛИЧНОСТЬ УКРАИНСКОЙ ДЕЛОВОЙ ЖЕНЩИНЫ НА СТРАНИЦАХ ЖУРНАЛА “ЖІНКА» (“ЖЕНЩИНА»)}

Аннотация. В представленной статье анализируются особенности вербализации образа деловой женщины на страницах журнального периодического издания "ЖЖінка) ((Женщина»). Дель исследования - систематизировать особенности вербальных средств репрезентации идентичности деловой женщины в текстах периодического издания; описать формирование языковыми средствами стереотипов феминности в постсоветский период истории Украины; на материале публицистических текстов проанализировать трансформации традиционных гендерных стереотипов. Предметом изучения являются особенности коммуникативной личности украинской деловой женщины в период независимости страны. Результаты анализа особенностей речевого поведения деловой женщины приводят к следующим выводам. В текстах статей имеются англицизмы, заимствованные как термины для обозначения новых отношений в экономике; частотны также профессионализмы и шаблонные конструкции без эмоциональной окраски. Для речи женщин характерны вводные слова, которые не являются источниками лишней информации: их употребление помогает говорящему сориентироваться, сосредоточиться, делает высказывания чётче организованными. Тексты современного периодического женского издания характеризуются активизацией словообразовательных компонентов с коннотацией высшей оценки: супервумен, суперзвезда, суперфинал, мегашоу и др.; в речи современной деловой женщины на страницах журнала много иностранных слов, особенно это заметно в процессе описания опыта работы украинских женщин на мировом рынке. Это объясняется изменением ценностных ориентиров личности, открытостью украинского постсоветского общества и проникновением в различные сферы жизни общества новых понятий и явлений.

Ключевые слова: языковая личность, социолингвистика, деловая женщина, периодический журнал (अінка), гендерный стереотип, гендерная идентичность, феминность.

\section{Viktoriia 0. ULYANOVA,}

Lecturer of the Department of Foreign Languages of the Natural Sciences Faculties, Odessa I. I. Mechnikov National University; 24/26 Francuzskiy blvd., Odessa, 65058, Ukraine; tel. +38 0975276506; e-mail: vikaromanenko17@gmail.com; ORCID ID: 0000-0002-2821-1833

\section{LANGUAGE PERSONALITY OF THE UKRAINIAN BUSINESS WOMAN ON THE WOMAN'S JOURNAL}

Summary. The article presents the features of verbalizing the image of a business woman on the pages of the periodical "Woman". The purpose of the article is to deepen and systematize the features of the verbal means of defining the identity of a business woman in the texts of the periodical magazine, as well as to reflect, function and transform traditional gender stereotypes and the formation of stereotypes of femininity in the post-Soviet period of Ukrainian history. The subject of this research is the linguistic personality specifics of the Ukrainian business woman during the independent epoch of Ukraine. The results of the analysis of business woman's speech features make the following conclusions: the texts of the articles appear English, borrowed terms to indicate new relations in the economy, often use professionalism and patterns without emotional color. The speech of women is expressed by expletive words, but they do not create unnecessary information, their usage helps the speaker to orient, focus, and makes the expression more organized and clear. Also, the texts of modern periodicals are characterized by the activation of various word-forming components, for example, to signify exaggerated meaning: superwoman, superstar, etc. The speech of the modern business woman of the 
magazine is distinguished by the use of a large number of foreign language words, especially when describing the market experience of Ukrainian women. This is explained by the change of values of personality, openness of post-Soviet society and penetration into different spheres of society of new concepts and phenomena.

Key words: linguistic personality, sociolinguistics, business woman, periodical (Zhinka» (“Woman»), gender stereotype, gender identity, femininity.

Статтю отримано 20.10.2019 p. 